\title{
The Outline of Personhood Law Regarding Artificial Intelligences and Emulated Human Entities
}

\author{
Kamil Muzyka \\ The Institute for Ethics and Emerging \\ Technologies \\ Trinity College \\ Hartford, CT, USA
}

TYGRZYKI986@02.PL

Editors: Randal Koene, Diana Deca

\begin{abstract}
On the verge of technological breakthroughs, which define and revolutionize our understanding of intelligence, cognition, and personhood, especially when speaking of artificial intelligences and mind uploads, one must consider the legal implications of granting personhood rights to artificial intelligences or emulated human entities.
\end{abstract}

Keywords: AI, artificial intelligence, corporate personhood, mind upload, infomorph, ent, robot, personhood, legal person, law

Until recent times, the ideas of whole brain emulation and the personhood of artificial intelligences ${ }^{1}$ were considered the sole domain of science-fiction literature ${ }^{2}$, but both concepts are fast becoming the subject of philosophical disputes and the concern of cognitive scientists and lawyers alike.

From a legal perspective, personhood is the possession of the general legal capacity and the capacity to make acts in the law, (either full or limited, depending on additional criteria). Entities with personhood are divided further into natural persons and legal (or corporate) persons. The concept of legal personhood pertains to legal entities such as corporations or government institutions, but it is natural personhood which will be of central concern for the purposes of this paper.

A natural person is defined as each human being from the moment of conception to the moment of being pronounced dead. However, the national law of many countries tends to avoid issuing clear statements on "who or what is a human being?"33. It is not the mind which makes us human, for a child born with anencephaly is still

1 Hereinafter abbreviated as "AIs."

2 Hard science fiction and cyberpunk in particular. A good example would be the Takeshi Kovacs (mainly the Altered Carbon) novels by Richard K Morgan or the Gamedec series (particularly The Locomotive Dealers, pol. Sprzedawcy Lokomotyw) by Martin Ann, the major plot-lines of which revolve around both these topics.

3 An issue that has been regularly evaded since the end of World War II and the signing of the Universal Declaration of Human Rights on the $10^{\text {th }}$ of December 1948.

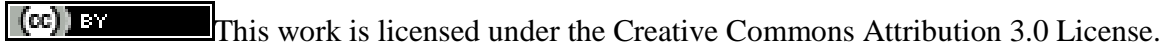




\section{MUZYKA}

regarded as a human being. Nor is it the body, as deformed children are human beings nonetheless. The conclusion is simple - a human being is an offspring of two human genetic material donors (Malinowski, 2007) . $^{4}$

Theoretically, in such a legal environment, any discussion of the personhood of AIs and Infomorphs (Chislenko $1996)^{5}$ seems to be lacking sense, or even the slightest possibility. The problem of legal science in many countries is the lack of foresight - most changes are introduced in reaction to some event, most often an unforeseeable accident or an unpreventable catastrophe.

When looking on present day digital technology and the availability of internet connections, together with electronic signatures, there is no actual need for a person (either natural or legal) to appear "in the flesh" to sign an agreement. It would seem probable for an artificial intelligence entity to run its very own accounting office, logistics, or any other outsourceable department that can be run remotely and independently. Instead of an entire office with its departments of accountancy, human resources, public relations, as well as secretaries, and the board of executives, we could imagine a single sapient program possessing the computing power and processor capacity required to manage all operations at once, and with high standards. All matters which should be dealt in a courtroom would be handled via its counsel. In this case, an AI entity would not only meet the requirements to run a private enterprise, but would in fact be both that company and a legal person at the same time. A machine would not have any difficulties in providing services, trading assets, or even speculating on the market, in the same manner as BIs (business intelligences) do on the New York Stock Exchange (Salmon, Stokes, 2010).

In his paper "The Criminal Liability of Artificial Intelligence Entities", Gabriel Hallevy describes three models of the criminal liability of artificial intelligences (Hallevy, 2010). The first option is to consider the creator of an AI liable for every crime the AI commits. A second approach would be to make the user and constituent of an AI liable. The third model is predicated upon the direct responsibility of the AI itself. When discussing a fully autonomous AI entity, one must take into consideration its full legal liability for any actions it takes (Lehman-Wilzig, 1981). There is an ongoing debate in the United States regarding the so-called corporate punishment and corporate personhood. Both of these institutions would be perfectly fit for the legal personhood of an AI, if it were not for one very sad fact that this idea must face.

It is quite improbable that a written program, being intelligent and achieving awareness, would be set free to roam the world and develop by itself, do scientific research, run companies, or even hold an office ${ }^{6}$. From a pragmatic point of view, corporations or other entities creating or establishing AIs would rather acquire a sort of an electronic jinn, an instrumentum vocale ${ }^{7}$, which they could order to do anything they want, thus gaining high profit at low maintenance $\operatorname{costs}^{8}$ without the fear of being sued for health deterioration from working conditions. We are most likely to expect situations, in which the concern of large workplace reduction would result in the introduction of some kind of personnel parities ${ }^{9}$. It would be very improbable for the CEO and the board of executives to give up their salary and jobs in the aftermath of recognizing their asset as a person.

4 The issues of over-fertilization, parthenogenesis, maternal spindle transfer or cloning are not particularized here, for in all of those cases the donor or donors are still human beings.

5 The term infomorph is a popular one among writers and readers of science fiction, as well as futurologists. It denotes digitalized or emulated human entities stored on data-storing hardware, with the form of interactive software. It was coined by Charles Platt in his novel The Silicon Man and later adapted by science due to Alexander Chislenko's Networking in the mind age.

6 In the case of a natural personhood, which in fact many corporations want to be recognized as. Applying this term to an AI would allow it to hold an administrative or government office, vote and be elected, or even be a member of the Council of Ministers.

7 Or res vocale, (latin for speaking thing or talking tool) an ancient roman term for slaves.

8 Canceling corporate departments working on a three shift table, replacing them with a AI.

9 It would be based on a compulsion from the top, requiring the company, which replaces its departments with AI's to hire a certain amount of employees, say \% of the necessary personnel for that kind of job. One can suppose that this solution is economically ineffective, but the parity politics is introduced for ideological purposes, not free-market economy. 
However, some scholars have very different ideas about this. In their collaborative paper "Liberating Intelligent Machines with Financial Instruments", the authors describe a legal and financial system, which allows for artificial intelligence to properly function as an autonomous legal entity through a set of obligatory insurances, liability stocks, although not necessarily viewed as a legal person (Huttunen et. al., 2010).

We should now consider the legal status of the second of the above-mentioned entities, namely an emulated human entity (The Mind Uploading Project), which could likely be named an "ent" ${ }^{10}$. For the time being, there are no physical examples of emulated human beings, brain-scanned personalities, or uploaded minds in the form of backup copies, but we are on the verge of the so-called Brain Race (Lepisto, 2013). The competition is between several main projects, including The Human Brain Project, BRAIN Initiative (Markoff, 2013), sometimes called the "Obama Brain Project", and the Human Connectome Project". The goal of these projects is to create the world's first virtual simulation of the brain by scanning its neural structure, finding out how it works, searching for causes and cures to many diseases, and making an impact on many fields of electronics, as well as the general information industry. One of the possible outcomes of such an endeavor could be the creation a working, active copy of a human mind, with which one could communicate. According to Ray Kurzweil and other transhumanist futurologists and scientists, this method could help people achieve immortality (Didymus, 2013). At this point in time, the most basic question, both philosophical and legal, is whether such an uploaded mind could still be considered a human being.

This is probable in the case of an active backup copy. When taking into account the cost of the procedure itself, people who could afford to be uploaded could also afford lawyers and lobbyists who would be able to prove before any supreme court that an ent should be recognized as a human being ${ }^{11}$. On the other hand, similar claims have been made in the cases of primate (Fox, 2012) and cetacean ${ }^{12}$ personhood laws. The animals were only granted the humane legal protection against being held in captivity, suffering physical harm, or any kind of abuse, but were not granted full legal liability for their actions and are not considered entities capable of performing acts in the law. Nevertheless, an analogous legislation could result in granting a certain set of personhood rights to the product of whole brain emulation.

This idea raises a lot of questions and concerns regarding civil and criminal law. There is no doubt that a person would like this ent, who is their backup copy, to immediately step into their rights, after he or she has passed away. This would mean that right after the original has been deceased, the backup would run the original owner's company, receive his or her rights from patents or copyright, or would hold the same office. Concerning the issue of inheritance, one can suppose that the "backup" would have precedence before the spouse and the children, or even that the sole fact of the existence of a backup copy would foreclose all inheritance proceedings. The issue of possessing a mobile storage device in the form of a robotic body would expedite things for that person in a large numbers of instances, especially in the context of people as physical entities (Pinchefsky, 2013). It is morally difficult to discuss whether a person could have an active copy while the original "flesh" is still alive.

Legislative acts should provide us with a solution that in the above-mentioned circumstances, the ent is to be treated as an adolescent according to the law, i.e. like a person between thirteen and eighteen years old. This concept would result in all legal actions such as signing agreements, making obligations, disposing larger funds, chattel, or estate, requiring the countersign of the original. Such a state would last

10 The term is shorthand for entity.

11 There are examples of legal regulations like this which have been passed, including the European Council's directive claiming that carrots are fruits (http://eur-lex.europa.eu/LexUriServ/LexUriServ.do?

uri=CELEX:32001L0113:En:HTML), or that a snail is an inland fish.

12 An official statement by the Indian Ministry of Environment and Forests is Retrieved from http://cza.nic.in/ban\%20on\%20dolphanariums.pdf 
exactly five years ${ }^{13}$, after which the ent would acquire full legal personhood. The main reason behind such a solution is the creation of a separate persona through different experiences and feedback. Another reason is to prevent an individual from instantly creating legions of ents, which would then take over the board of executives and most of the important structures of a corporation. The alternative is to freeze ents and keep them in that state until such time that the original is pronounced dead, after which the ent would be activated and automatically step into the rights of the original. What can raise moral concerns is the possibility of activating an ent while the original is in a terminal state such as a coma. Would the ent have the right to "pull the plug" on the vegetative original body?

Another crucial issue is the liability of ents for their crimes. As the perpetrator, an ent would pay the fine with its own wealth. In the case of a felony, there would probably be a death sentence involved, as Hallevy (2013) noted in his work. The other alternative would be going through a particular kind of therapy during the time of serving its punishment, or even a forced data modification, similar to a software patch, which would alter the ent's behaviour. Applying incarceration or freezing an active ent might be devoid of reason, for it would not teach the sentenced ent the proper social behaviour, but rather, achieve just the goal of isolating it from the rest of society, so that it would no longer be a threat. One crucial role of the prison sentence is rehabilitation. The ent serving its sentence would not grow old, although its brain structure would change constantly through gaining further experience in the course of its constant work. Furthermore, its body and storage device could be changed for a newer replacements, so its health would not deteriorate, making social rehabilitation or enforced behavioural patching even more crucial.

One might recall the SOPA case ${ }^{14}$. The deep packet inspection mechanism (Porter) could prove quite useful as a countermeasure that would prevent the AIs or ents from swarming out into the Internet and stop them from reproducing in an uncontrollable manner by finding and neutralizing them, the same way as if they were illegal or counterfeit files.

As far as treating ents as human beings is concerned, the issue of artificial prosthetic bodies should be taken into account. A prosthesis is an artificial device used to replace a body part or an organ which has been lost due to an accident, disease, or other factors. At this time, we can assume that people will be able to print a spare organ in the time span of several hours (Renard, 2013). In the case of ents, organ printing is not likely ${ }^{15}$. It would be more likely to build them a full prosthetic body, which would store their persona. For the purposes of this paper, the popular question "after how many cybernetic implants and prosthetics a human stops being a human", is being set aside. In some sense, an ent could be treated like a person with a disability, possessing an array of prosthetics or bionics, necessary for them to continue living and function properly.

The issue of an ent entering a domestic partnership or marriage, or raising children, would be legally recognized as follows. Should we consider the ent to be a person possessing full personhood rights, it would have the right to each legal action mentioned above. Its biological offspring could be developed via in vitro fertilization, with the use of genetic material extracted from the "original" before its death.

13 The time required for the adolescent to reach adulthood.

14 Stop Online Piracy Act. Retrieved from http://thomas.loc.gov/cgi-bin/query/z?c112:H.R.3261:

15 Even in a close future it would be impossible without some miraculous nanotechnology like neurobots - nanobots able to reconfigure the neurostructure of the brain - to "upload" a person into a fresh brain. There would be an option to print an entire brain based on the uploaded blueprints. However, creating an anaencephalic clone body, or a printed replica, just with the aim of imprinting a brain containing the uploaded person inside, or printing a complete brain with a body, would perhaps be too much of a complication of the "reconvalescence" process and the "posttanatic therapy." 
The case of sexuality or gender could cause some controversies, as persons with full prosthetic bodies would have no natural reproductive organs, and would be able to choose their own sex from the four available $^{16}$. The matter of ents having or lacking a sex drive could be an excellent topic for scientific, even theoretical research, but has no meaning in the case of their legal recognition.

Going further into the future, although it would be perhaps much more accurate to call this process exploring existing possibilities, we should also consider the matter of data clouds and cloud computing (Smith, 2013). An ent existing in cloud storage would be able to operate a robotic body remotely. Looking at the matter in a simple way, one could assume that the ent would take full responsibility for actions taken via its remote body. However, there should be a legal countermeasure against abusing such technologies, like a form of a digital "ID," by which such ent could be traced, sued, judged, and sentenced.

In conclusion, the acquisition of human status and personhood rights by ents is an unlikely scenario due to our anthropocentric view of personhood. Artificial intelligences would most likely be treated as advanced tools. Eventually, in some case they would be treated similar to autonomous UCGV or drones. In the second instance, they would be likely held liable for exceeding collateral damage, as well as for war crimes (Weng, Chen, and Sun, 2009), while the responsibility of their commanders and constructor would be abolished (Roff). Our atavistic reaction might lead us to recognize ents as humans lacking a human or humanoid body more so than as artificial beings, created from scratch, pretending to be human (Gee, Brown, and Kawamura, 2005).

\section{References}

Chislenko, A. 1996. Networking in the Mind Age. Retrieved from http://penta2.ufrgs.br/edu/telelab/ 10/mindage.htm

Didymus, J.T. 2013. Google's Ray Kurzweil: 'Mind upload' digital immortality by 2045. Retrieved from http://digitaljournal.com/article/352787

Fox, J. 2012. Great Ape Personhood. Retrieved from http://erepository.law.shu.edu/cgi/viewcontent.cgi?article=1102\&context=student_scholarship

Gee, F.C.; Browne W.N.; and Kawamura, K. 2005. Uncanny Valley Revisited. IEEE International Workshop on Robots and Human Interactive Communication. Retrieved from http://ieexplore.ieee .org/xpl/login.j sp?tp=\&arnumber $=1513772 \& u r l=h t t p \% 3 \mathrm{~A} \% 2 \mathrm{~F}$ \%2Fieeexplore.ieee.org\%2Fxpls\%2Fabs_all.jsp\%3Farnumber\%3D1513772

Hallevy, G. 2010. The Criminal Liability of Artificial Intelligence Entities. Retrieved from http://papers.ssrn.com/sol3/papers.cfm?abstract_id=1564096

Human Connectome Project. Retrieved from http://www.humanconnectomeproject.org/

Huttunen, A.; Kulovesi, J.; Brace, W.; Lechner, L.G.; Silvennoinen, K.; and Kantola, V. 2010. Liberating Intelligent Machines with Financial Instruments. Retrieved from http://www.njcl.utu.fi/2_2010/huttunen_anniina.pdf

16 Female, male, ambigender, or bigend - a hermaphrodite; and a nogender, or non-gend — an individual lacking reproductive organs. 
MUZYKA

Lehman-Wilzig, S.N. 1981. Frankenstein Unbound-Towards a Legal Definition of Artificial Intelligence. Retrieved from http://profslw.com/wp-

content/uploads/academic/40._Frankenstein_Unbound.Towards_a_legal_definition...pdf

Lepisto, C. 2013. Will Brain Race Be This Generation's Moon Race? Retrieved from

http://parentables.howstuffworks.com/health-wellness/will-brain-race-be-generations-moon-race.html

Malinowski, W. Czy można zajść w kolejną ciążę, będąc już w ciąży? Świat Nauki 240. Prószyński Media.

Markoff, J. 2013. Obama Seeking to Boost Study of Human Brain. Retrieved from http://www.nytimes.com/2013/02/18/science/project-seeks-to-build-map-of-human-brain.html? pagewanted=all\&_r=0

Pinchefsky, C. 2013. Dmitry Itskov Wants To Live Forever. (He Wants You To Live Forever, Too). Retrieved from http://www.forbes.com/sites/carolpinchefsky/2013/06/18/dmitry-itskov-wants-to-liveforever-he-wants-you-to-live-forever-too/

Porter, T. The Perils of Deep Packet Inspection. Retrieved from http://www.symantec.com/connect/articles/perils-deep-packet-inspection

Renard, M. 2013. Organovo Describes First Fully Cellular 3D Bioprinted Liver Tissue. Retrieved from http://ir.organovo.com/news/press-releases/press-releases-details/2013/Organovo-Describes-First-FullyCellular-3D-Bioprinted-Liver-Tissue/default.aspx

Roff, H.M. Killing in War: Responsibility, Liability and Lethal Autonomous Robots. Retrieved from http://www.academia.edu/2606840/Killing_in_War_Responsibility_Liability_and_Lethal_Auto nomous_Robots

Salmon, F.; and Stokes, J. 2010 Algorithms Take Control of Wall Street. Retrieved from http://www.wired.com/magazine/2010/12/ff_ai_flashtrading/

Smith, M. 2013. How Cloud Computing Works : Pros and Cons of Cloud Computing. Retrieved from http://techyyouth.com/2013/04/how-cloud-computing-works-pros-and-cons-of-cloud-computing

The Mind Uploading Project. Retrieved from http://minduploadingproject.org/

Weng,Y.H.; Chen, C.H; and Sun, C.T. Toward the Human-Robot Co-Existence Society: On Safety Intelligence for Next Generation Robots. International Journal of Social Robotics 04.2009.

Retrieved from http://works.bepress.com/cgi/viewcontent.cgi?

article $=1000 \&$ context=weng_yueh_hsuan

Williams, C. Stem cell fraudster made 'virgin birth' breakthrough: Silver lining for Korean science scandal. The Register: 03.08.2007. 